\title{
CRL 1005
}

National Cancer Institute

\section{Source}

National Cancer Institute. CRL 1005. NCI Thesaurus. Code C2211.

A nonionic block copolymer adjuvant used to enhance viral or non-viral polynucleotide delivery in gene therapy vaccines. 